\title{
Aid Conditionality in African Higher Education - The Case of Cameroon: Implications for Multinational Finance of Education and Educational Policy Borrowing
}

\author{
Joyce Afuh Vuban
}

\begin{abstract}
Department of Education, York Graduate School, University of York, York, YO10 5DD, United Kingdom.
\end{abstract} vja503@york.ac.uk

\begin{abstract}
Conditionality has always been an integral aspect of multinational aid schemes for so many decades. While some studies have been conducted on aid conditionality across different aspects of development, human social existence, educational sectors and contexts; less attention has been paid to what goes on within the framework of higher education (HE) especially in Africa at large and Cameroon in particular. Using interviews, focus group discussions and text documents, this article examines academic conditionality perceived as negative, metaphors of aid conditionality depicting problems, and some implications of aid conditionality for multinational finance of higher education institutions (HEIs) and educational policy borrowing in Africa/Cameroon by learning from existing literature. Conclusively, the article suggests that multinational aid donors should be encouraged to reinforce academic conditionality perceived as positive, and not academic conditionality perceived as negative in order to obtain a win-win relationship with aid recipients.
\end{abstract}

Keywords-Aid conditionality, African higher education, educational policy borrowing, implications, multinational finance of education.

\section{INTRODUCTION}

Africa is a financially poor continent (World Bank, 2014; \& African Development Bank (AfDB), 2015), and African governments wrestle within their means to fund different sectors of their national economies which includes investments in HE. Investments in HE is considered crucial through its returns or dividends in terms of skilled human capital needed for national development (Mbua, 2002). According to Barro (1991), Rebelo (1991), Benhabib and Spiegel (1994), Barro and Sala-i-Martin (1998), and NiñoZarazúa (2016, p.1), a sound education policy that encourages the development of knowledge and processes of technological and scientific innovation is therefore needed www.jiels.com for both economic growth and developmental processes of any given nation - including policies for aid schemes for African HE. It has been argued that (Kanbur, 2000, p.2) there has been '... an exhaustive, and exhausting, debate on aid, conditionality and debt' in the last fifteen years, with the gravity of the current debate situated in Africa; and with Africa failing to attain significant progress to satisfy the well-being of its entire populace. While some blame Africa's debt burden, others blame conditionality (p.2).

According to Spevacek (2010, p.2), aid conditionality can be traditionally defined as '...an exchange of policy reforms for external resources'; however, theoretically, noncompliance tend to jeapardise donor support, but failure to comply does not always lead to a loss of donor funding. There are many benefits of aid benefits in education. NiñoZarazúa (2016, p.4) for instance pointed out that, activities related to the supply-side capabilities of educational systems that have mostly been supported by donor agencies include the training of teachers, the provision of education facilities, and support for education policy and administration management.

Several studies have been carried out on aid flow to basic education accelerated by the adoption of the Dakar Framework for Action which consolidated the commitments of the international community to achieve Education for All by 2015 (Carr-Hill and King, 1992; UNESCO, 2000; Steer and Wathne, 2010; Niño-Zarazúa, 2016; d'Aiglepierrea and Wagner, 2013; Birchler and Michaelowa, 2016; Riddell and Niño-Zarazúa, 2016); or aid flow to enhance development (Tilak, 1998; Laura, 2010; Novelli, 2010; Ashford and Biswas, 2010); or simply HE finance across contexts (Temple, 2010; Jacob and Gokbel, 2018; Teichler, 2018; Marginson, 2018; Jacob, Neubauer and Ye, 2018; Kim and Park, 2018). Furthermore, while some research into policy borrowing and aid conditionality have been 
carried out by Steiner-Khamsi (2006) who analysed the economic reasons of policy borrowing and lending while stressing on aid conditionality; and Eta and Vuban (2018) who examined policy borrowing as a debatable paradigm using aid conditionality for illustration; however, there is still lack of substantial attention paid to research on aid conditionality within African $\mathrm{HE}$ at large and Cameroonian $\mathrm{HE}$ in particular in the advent of educational policy borrowing - a gap which this article addresses. This article contributes to knowledge within the field of HE finance by addressing this gap. To this effect, this article aims at:

examining academic conditionality perceived as negative; metaphors of aid conditionality depicting problems; and some implications of aid conditionality for multinational finance of HEIs and educational policy borrowing in Africa/Cameroon by learning from existing literature.

This article illustrates that multinational and to an extent bilateral aid conditions (or conditionality) are the bases on which financial commitments are respected within African/Cameroonian HE. The article presents literature on: aid conditionality debates; conceptualisation of multinational finance of $\mathrm{HE}$ and educational policy borrowing through the lens of aid conditionality; methodology of the study; findings (results and discussion); and conclusion.

\section{Existing debates on aid conditionality: pros and cons}

Over the years, there have been increasing debates centered on aid conditionality. According to Spevacek (2010, p.2), on one hand, aid conditionality has been argued to serve as a positive foreign influence for governments that are weak but willing to institute democracy in which reforms would have unambiguous impacts on poverty reduction and growth. On the other hand, it has been argued that traditional aid conditionality has not yielded success as it has the tendency of subordinating the needs of the poor, and it is hardly enforced, thus serving as a discredit to the entire aid process (p.2). To Oxfam (1995), while conditionality could bring about favourable policy reforms with donors and governments in principle agreeing to take steps geared at raising investments in water and sanitation, basic education and primary health care; however, most donors are perceived to reject this approach based on the fact that this has potentials of undermining the national sovereignty of governments of developing countries. For instance donors through the Structural Adjustment Programmes
(SAP) have obliged governments to: liberalise markets, privatise industries, fix interest rates at levels dictated by the IMF, devalue currencies and impose fees for primary education (Oxfam, 1995). According to Kanbur (2000, p.8) on one hand, aid dependence has led to the disbursement of large funds from donor agencies while presumably checking accountability for these funds to donor country taxpayers. On the other hand, aid dependence diverts attention form national debates, consensus building and provides the impression that national governments tend to dance to the tune of donors which has an adverse effect on national political economy (p.8). Kanbur (2000, p.8) added that Africa for instance suffers considerably from aid dependence in terms of real cost as too much time, national energy and political capital is always spent in its policymaking, interaction with foreign aid donor agencies, servicing donor consultants, use of the "weakness of strength" maneuvered against the donors and engagement in routine activities of reporting to donors. Spevacek (2010, p.2) reiterated that recent studies have portrayed that conditionality has not proven to be effective in social change, economic growth and policy reform. For instance, an OECD brief in 2009 reported that stringent conditionality does not work because national governments tend to become increasingly accountable to donors than to preferences of their citizenry which intend weakens recipient ownership of reform processes and suppresses national debates ${ }^{1}$. From these debates, I argue that aids offered to recipient nations have both positive and negative outcomes. This explains why examining academic conditions in African $\mathrm{HE}$ perceived as negative and not positive is timely.

\section{Conceptualising multinational finance of education and educational policy borrowing through the lens of aid conditionality}

According to Mbua (2003, p.495), 'educational financing' also known as 'financing of education' is defined as 'the allocation of financial resources used to invest in education by the state, parents and communities and organisations' (p.496). This means multinational finance of education can be defined as the financial resources invested in education by multinationals. Mbua (2002 \& 2003) and the World Bank (2010, p.94) affirmed that foreign agencies (bilateral and multinational bodies) are some of the key sources or methods of educational finance. There are many reasons for financing education (Mbua, 2002). These include: the right

\footnotetext{
${ }^{1}$ OECD stands for Organisation for Economic Co-operation and Development.
} 
to education; education as private and social investment; education as an agent for economic growth; and education as a means to eradicate illiteracy. Freeman (2003, p.321) added that multinational corporations are specifically essential to ensure the viability and survival of HEIs in nations that are undergoing economic and political change (like Africa).

According to the World Bank (2010), Sub-Saharan Africa was the second largest recipient of aid to $\mathrm{HE}$ between 2002 and 2006. It is perceived that national resources are not sufficient enough to support the large number of mobile African students thus needing international aid as an important source of finance. Between 2002-2006, external donors allocated an average US\$3.3 billion yearly to HE globally. From this amount, 18 percent, or approximately US\$600 million, was allocated to SubSaharan African countries. Most multinational and bilateral donors assist to finance HE in Africa (p.95). According to the World Bank (2010):

The largest donor was France, with more than US\$300 million allocated annually during 200206, followed by Germany (US\$95 million), Portugal (US\$37 million), the International Development Association (US\$34 million), Belgium (US\$25 million), the Netherlands (US\$21 million), the United Kingdom (US\$17 million), Norway (US\$16 million), and the European Commission (US\$11 million). (World Bank, 2010, p.95).

The World Bank (2010, p.95) also noted that resource allocations to $\mathrm{HE}$ are much lower in comparison to basic education. Between 2002-2006 for instance, annual aid to basic education in Sub-Saharan African countries was more than US\$1.1 billion; and this was about twice the amount allocated to HE (p.95). There are two kinds of aid allocated to HE. These include 'direct external aid' and 'indirect external aid' (World Bank, 2010, p.96-101). While direct aid is mostly financial assistance, the World Bank (2010, p.97) noted that a portion of such direct aid to HE goes to assist research centers and universities to implement their teaching and research programmes. Furthermore, such aid can be in the form of: supply for equipment (books, IT); financing of technical support to create curricula and programmes; and building of infrastructure. However, many donors also place emphasis on language programmes aimed at fostering the utilisation of their language with the partner HEIs (p.97). On the contrary, indirect external aid to HE by bilateral (or multinational) donors take the form of support to African students studying abroad such as scholarships. However, '...the amount of aid is determined by imputing the cost of educating these students in foreign universities' (World Bank, 2010, p.101).

According to Phillips (2000), policy borrowing involves a process of learning and understanding what is happening in another national context; which Dolowitz and Marsh (2000) perceive to be aimed at solving similar problems or improving/developing provisions in other systems. To Verger, Novelli and Altinyelken (2012, p.23), International Organisations (IOs) exercise various kinds of power which includes the control of information; data; and expertise. Other than financial power, Vuban (2018) noted that IOs have used expert power to spread best practices in $\mathrm{HE}$ across the globe (Africa/Cameroon inclusive) which is evident in the processes involved in the transnational flow of the European Bologna Process to contemporary African and Cameroonian $\mathrm{HE}$ for instance - hence the onset of educational policy borrowing in present-day HE. Vuban (2018) noted that neoliberal structures such as the World Bank, UNESCO among others are key players that assist in educational policy borrowing. Eta (2018, p.43) for instance also remarked that in Africa, the adoption of the Bologna Process, the Nyerere Mobility Programme, the Tuning Africa Project and the AUCEU (African Union Commission-European Union) partnership to support the harmonisation of HE programmes in Africa is known to be heavily funded by the European Union.

Educational policy borrowing is not only a multifaceted concept but provides reasons governing aid conditionality through multinational finance of HE. According to Vuban (2018), conditionality is a crucial aspect of 'dominance'- a leading factor of policy borrowing in African/Cameroonian HE systems. ${ }^{2}$ Dominance (to which aid conditionality is part of) is lodged within Vuban's theoretical framework known as the 'policy borrowing iceberg'; and this indicator is situated within the category 'analysis beneath the iceberg'. Vuban argued that with the iceberg metaphor, there is a hidden or covert aspect of policy borrowing in Africa at large and Cameroon in particular which is apparently more 'dangerous' as this triggers hurtful feelings

2 According to Vuban, 'dominance' indicators include: dependency, control, aid conditionality, western dictatorship, imposition, and unequal power relations. These indicators propel 'dominance' to serve as a facilitating and/or inhibiting (or problematic) factor of policy borrowing. This means 'dominance' and its corresponding indicators present policy borrowing in Africa/Cameroon as a paradox and/or a controversial phenomenon.

Page | 375 
among recipients of borrowed educational policies (or consumers of aid donations). In this regard, multinational aid finance of $\mathrm{HE}$ is not always a favourable venture for Africa as a continent at large and its HE systems in particular - as this can be unfavourable too.

According to Steiner-Khamsi (2006) the economics of policy lending and borrowing, aligns to the economic reasons for borrowing a specific education reform. In other words, the economic justification for policy borrowing refers to a situation in which policy adoption is aiddependent, that is a 'precondition for receiving aid' from donor agencies and international organisations; and in line with this, the implementation of such borrowed policies may only last if there is external funding. Steiner-Khamsi (2006) remarked that, indeed a time has come for nations to have a specific reform when international funding for implementing that particular reform is secured. The economics of policy lending and borrowing also helps to explain why education reforms in low income nations increasingly bear a resemblance to those in developed nations (Steiner-Khamsi, 2006). According to Levin (1998), initially one sees much commonality in the themes that emerge across countries, suggesting that national and regional governments do learn (or borrow) from each other and the rationale why nations learn (or borrow) from each other largely tie with economic rationales for change. These include, first, the need for change in education is largely cast in economic terms and particularly in relation to the preparation of a workforce and competition with other countries (Levin, 1998, p.131). Second, educational change is occurring in the context of large-scale criticism of schools as government policy documents typically take the view that school systems have failed to deliver what is required and that the failure is especially lamentable in view of the high level of spending on education. Third, large-scale change is not accompanied by substantially increased financial commitments to schools by governments posing problems in education (Levin, 1998, p.132). Fourth, considerable attention has been given to making schooling more like a commercial or market commodity' (Levin, 1998, p.133). Samoff (2001), Chisholm and Leyendecker (2008) and Vavrus (2004) therefore affirmed that the economic rationale for policy borrowing is known to be common amongst underdeveloped nations that are aiddependent - needing change or reform in their HE systems (Vuban, 2018). ${ }^{3}$

3 In brief, the 'policy borrowing iceberg' is a novel theoretical framework which Vuban developed in the course of her $\mathrm{PhD}$, thus a significant theoretical contribution to www.jiels.com

\section{METHODOLOGY}

Before delving into the data collection process, it is of importance to be conversant with knowledge regarding the area of the study. In brief, Africa is the second most populated and the second largest continent in the world after Asia. It has a surface area of $30,370,000 \mathrm{~km}^{2}(11,730,000 \mathrm{sq}$ miles) and occupies six per cent of the earth's total surface area (Sayre, 1999). In 2017, the population of Africa was 1.256 million people (United Nations, 2017) and this accounts for approximately 16 per cent of the human population across the globe. It is characterized by slave trade and colonialisation which took place in the past, and a rich culture (with numerous ethnic languages, arts, music and dance, sports and religion). In terms of the economy, in 2018, Africa's Gross Domestic Product (GDP-nominal) stood at \$2.33 trillion; GDP (PPP or Purchasing Power Parity at \$6.74 trillion; and GDP per capita at \$1,890 (IMF, 2018). Education has always been part of Africans evolving from informal or indigenous education (Ajayi, Lameck, Goma and Johnson, 1996) to colonial education (MacOjong, 2008) and finally post-independence education. Africa is made up of 54 sovereign and fully recognized states or countries, nine territories as well as two de facto independent states with insignificant or no recognition. These states are broadly governed by the African Union.

One of such countries (which is the case of this study) is Cameroon which is located in the west of Africa. Cameroon was colonised by France and Britain after the defeat of the Germans in German Kamerun during the First World War (Tambo, 2003; Fonkeng 2007; Ngoh, 2011 and Ebongue, 2017). While France had the greater share $(80 \%)$ and ruled its part of Cameroun from Yaounde with other French colonies of the region; Britain had the smaller share $(20 \%)$ and ruled its part from Lagos-Nigeria. During the struggle for independence in Cameroon, French Cameroun gained independence in 1960 while British Cameroons did

knowledge. She argued that existing models in comparative studies such as policy borrowing, policy transfer, policy convergence etc are Euro-centric as these have been produced by westerners following western realities. While African realities have been neglected by these existing models, African realities are again hardly properly examined using these models as theoretical frameworks in African research or discourses. The 'policy borrowing iceberg' supports, challenges and builds upon the aforementioned models. Since the policy borrowing iceberg has been designed based on Afro-centric realities in relation to western influence, the framework is more suited in analysing Afro-centric discourses in comparative studies. In other words, the framework will aid in examining westernoriented policies, reforms, practices, programmes etc in Africa.

Page | 376 
same in 1961. The colonial cultural heritage led to the use of English and French as official languages in Cameroon though the nation also has about 248 ethnic languages (Ebongue, 2017, p.316). Cameroon is made up of 10 regions, with the administrative capital being Yaounde and the economic capital Douala. 80 per cent of the economy is agrarian (Fonkeng, 2007) with the currency being the CFA Franc BEAC (XAF) which it shares with other countries in the Central African Economic and Monetary Community (CEMAC) region. The country is often referred to as 'Africa in miniature' based on its rich geographical and cultural diversity. Natural features include beaches, deserts, mountains, rainforests, and savannas. It has a surface area of $475,442 \mathrm{~km}^{2}$ and a population of about $24,982,895$ people. In 2017, the GDP (PPP) was $\$ 82$ billion. Cameroon is bordered by Nigeria to the west and north; Chad to the northeast; the Central African Republic to the east; and Equatorial Guinea, Gabon and the Republic of the Congo to the south. Relative to HE, Cameroon has 8 full fledge state owned universities (of which two are English-speaking) with many institutions of higher learning.

Data for the study was collected in Cameroon between 2015 and 2016. Institutions from which data was collected include: the African Development Bank (AfDB); l'Agence Universitaire de la Francophonie (AUF); Commonwealth department in the Ministry of External Relations (MINREX); Catholic University of Central Africa (UCAC); Catholic University of Cameroon (CATUC); St Monica University-The American University of Buea (SMU); Cameroon Christian University (CCU); Bamenda University of Science and Technology (BUST); University of Bamenda (UBa); University of Buea (UB); and the Cameroon Ministry of Higher Education (MINESUP). The study made use of qualitative research design (Poovey, 1995) employing two focus group discussions (of four participants per group) conducted on students and lecturers respectively; and 56 interviews. Interviewees comprised of directors of MINESUP, AUF and AfDB; secretary general of MINESUP, vice chancellors, deputy vice chancellors, directors of academic affairs and sub-directors of universities, vice deans, deans, heads of departments, faculty officers, and other senior academics. Patton (1990, p.184) stated that qualitative inquiries do not employ rules for selecting sample sizes as the selection of sample sizes are dependent on: resource availability, what will be useful, what will have credibility, research objectives and what the researcher desires to know. The selection of the sample size as seen above was done by making use of snowball sampling and purposeful sampling techniques as well as Patton's ideas of selecting sample sizes. Text documents have also been used in the analysis and these have been duly referenced. According to Halliday 1978 cited in Eta (2015, p.168), 'text documents' are 'meaningful passages with meaning-making potential'. Text documents used in the analysis include journal articles, online reports and multinational documents which address aid conditionality such as:

(1) Eta and Vuban (2018) - Educational policy borrowing in the Cameroonian higher education system: A debatable paradigm from stakeholder perspectives.

(2) Kanbur (2000) - Aid, conditionality and debt in Africa.

(3) Oxfam (1995) - The Oxfam poverty report.

(4) Spevacek (2010) - Aid and the "new" conditionality.

(5) Riddell and Niño-Zarazúa (2016) - The effectiveness of foreign aid to education: What can be learned?

Aid implications were not provided in the interview and focus group data, which explains why documentary analysis has been of importance. Where quotations have been recited from the first text, this action has not been for the sake of repeating ideas but a means of providing evidence to support claims and expand on meanings. However, the above texts have also been used to analyse data outside the context of aid implications.

The specific question that was asked to research participants that led to the framing of this paper was 'what factors facilitate/inhibit foreign policy adoption in African and/or Cameroonian universities?' Participants responded by raising that aid conditionality among other factors both facilitate and inhibit foreign policy adoption in African/Cameroonian universities while providing substantial evidence. Focus in this article has been on the inhibiting (or problematic) aspect of policy borrowing through aid conditionality which addresses academic conditions perceived as negative, and metaphors of aid conditionality depicting problems.

In the course of data collection, ethics was of top priority. For instance ethical guidelines such as avoidance of harm, anonymity, right to withdraw, informed consent, reciprocity, confidentiality among others were taken into consideration. Pseudonyms were assigned to participants to ensure anonymity. This has been done by using their status, an alphabet and the abbreviation of their institution (for instance university official-A:UB). Credibility of the research methods and data were ensured by presenting these to my thesis supervisor, research participants and Thesis 
Advisory Panel to cross-check. The study made use of thematic analysis. The NVivo software was used in generating nodes (themes) and this was based on common patterns or similar ideas raised by participants. Categories were later generated by grouping similar themes together. Despite the richness of the content of the data, some literature has been used in discussing findings geared at boosting criticality and reflexivity. According to Brinkmann and Kvale (2015), and Bryman (2016), one of the ways of analysing qualitative studies is to analyse findings by employing concepts, theories or literature raised in the study among other techniques. Situated in Africa/Cameroon, findings in this study can be transferred to other developing countries that benefit from multinational/bilateral aid schemes to enable them become more critical about the downside of aid conditionality. The study has potentials of informing decisions regarding the use of external sources of finance e.g multinational and bilateral sources of finance through aid schemes, as these have potentials of influencing $\mathrm{HE}$ reforms, policy, programmes and practices.

\section{FINDINGS}

It is perceived that there is no single approach to examining aid conditionality, but rather a set of strategies which are being used to trigger not only broad-based sustainable economic and political changes (Spevacek, 2010, p.2) but educational changes as argued in this paper. This article addresses academic conditions perceived as negative. Based on findings, the restriction of access to $\mathrm{HE}$; youth unemployment crisis; poor working conditions for university lecturers; and withdrawal of foreign expertise during foreign policy implementation are perceived as examples of academic conditionality perceived as negative. Findings also presents metaphors/analogies of aid conditionality depicting problems. These include: "he who pays the piper call the tune"; "there ain't no such thing as afree lunch"; and "aid to developing countries is colonialism in a new dress". Findings also presents implications of aid conditionality for multinational finance of HEIs and educational policy borrowing in Africa/Cameroon by learning from existing literature.

\section{Academic conditionality perceived as negative}

According to Kanbur (2000, p.3), aid is usually not directed towards good policy environments; and when directed towards poor policy environments, does not propel the latter to change. Oxfam (1995) added that there has been the imposition of the wrong kinds of conditions. Linking these arguments with what goes on within HE systems in Africa at large and Cameroon in particular portray a set of academic conditions which have been imposed on $\mathrm{HE}$ systems in these contexts considered as negative. To this effect, academic conditionality perceived as negative are simply those conditions that have academic-orientations levied by multinational aid donors on African (Cameroonian) HE systems which have negative educational outcomes. Implicitly, these conditions serve as inhibiting (or problematic) factors of educational policy borrowing within these contexts. Though derived from economic policies and global imposition from wealthy and powerful multinationals like The World Bank and IMF, academic conditions according to findings perceived as negative include: restriction of access to $\mathrm{HE}$; youth unemployment crisis; poor working conditions for university lecturers; and withdrawal of foreign expertise during foreign policy implementation.

In terms of poor working conditions for university lecturers perceived as a negative academic condition imposed by multinationals as a condition to benefit from foreign aid, an official said:

The staff of Cameroon are the poorest paid I am sure in the whole world.....When we actually went out for strike in the University of Buea that we wanted a salary increase at least to measure up with Senegal (as we took Senegal as a measure for comparison which was the lowest paid apart from Cameroon during that period); what they instead gave us was Research Modernisation grant which is now being paid once in every three months. We have asked them to put it in our salaries and they say if they do so IMF will not be happy that they are increasing salaries in Cameroon.... Multinationals are interested in all countries and not only Cameroon. According to them, when you are in the red zone and not economically buoyant, you should not be taking up salaries. (University official/lecturer-F:UBa:2015). (cited in Eta and Vuban, 2018, p.82).

From the quotation above, it can be argued that with poor salaries, lecturers develop low motivation for teaching and poor interpersonal relationships with students. Furthermore, with low salaries, lecturers become less assiduous; and this encourages them to invest their time securing jobs with private HEIs just to make earns meet. All these shortcomings have led to poor quality education. However, one cannot fully agree with the perception that poor working conditions for Cameroonian university lecturers (and those found in other contexts) is an intentional 
negative academic condition imposed by multinationals. There are other economic factors such as poor foreign trade, mismanagement in the use of natural and financial resources, corruption, high family dependency rates, lack of free social amenities which increases living costs, poor living standards, poor university-industry partnership where lecturers could do research and serve as consultants to get paid among other factors which sum up to shape poor salaries of workers in Cameroon including university lecturers. In other words, lecturers' salaries are especially low relative to other salaries in the country given the macro and micro-economic conditions Cameroon faces. An interviewee further stressed that the Cameroonian currency was also devalued and this made salaries very low, thus illustrating how economic policies and conditions have triggered poor socio-economic standards and welfare systems of academic staff. Therefore, as a means of solving aid conditional concerns related to poor working conditions for university lecturers, multinationals should encourage African/Cameroonian governments to encourage alternative income generating activities amongst universities as a means of generating more funds for universities which can be used to raise staff salaries. Furthermore, there is need for African governments to autonomously decide on staff salaries based on their financial capacities. These proposed strategies have potentials of impacting positively on the provision of quality education through staff welfare systems as well as influence multinational finance of $\mathrm{HE}$ and educational policy borrowing.

Findings also indicate that one of the negative academic conditions imposed by multinationals as a requirement for donations and aids in African/Cameroonian $\mathrm{HE}$ is the policy of restriction of access to HE. Thus:

In the late $70 \mathrm{~s}$ and $80 \mathrm{~s}$, the World Bank was against the development of higher education. It hurt higher education in this country - arguing that investments at lower levels of schooling yields more dividends or returns than investments in higher education. The same World Bank regretted afterwards and admitted that it has hurt the development of higher education in this country. (University official-A;UB:2015). (cited in Eta and Vuban, 2018, p.83).

Participants reiterated that Bretton Wood institutions like The World Bank and IMF; and the UN especially UNESCO have restricted Cameroon's HE admission policy of open access by curbing the number of students having access into HE through policies and finance. The World Bank (1999); and Bloom, Floetotto, Jaimovich, Saporta-Eksten, and Terry (2014), affirmed that the World Bank as well as other donors by the mid-1980s drifted away from HE by paying more attention to basic education. Participants added that the reason is because multinationals are discouraged from funding Cameroonian $\mathrm{HE}$ as they think the size of $\mathrm{HE}$ in Cameroon is too large but prefer funding primary education. On one hand, there is reasonable evidence to suggest that the restriction of access to $H E$ was a cost effective means of securing economic development, as multinationals might have been very critical of the long-term consequences of lack of employment opportunities or lack of job availability for university graduates. On the other hand, multinationals at that time might have failed to consider that the development of any nation lies in the hands of its quality and quantity of manpower - with universities playing the fundamental role of developing high quality manpower due to its professional, entrepreneurial and research-based skills it imparts on students. In addition to this, no nation can develop based on mere numeracy or literary skills which is the focal goal of primary education. Later on, according to the World Bank (2000, 2002 and 2011), and Altbach, Reisberg and Rumbley (2009), around the 2000s, renewed attention on competitiveness and rising support for basic education from other multinational financial donors and institutions led to the re-evaluation of the World Bank assistance for HE in the domains of science and technology, curricular reforms, educational standards and $\mathrm{HE}$ diversification. In addition, investments in educational sectors were accelerated by the International Finance Corporation (IFC) around the late 1990s with more attention paid to HE (IEG-WB, 2017, p.21). Despite these giant steps taken to promote $\mathrm{HE}$ development in contemporary African societies, the development of quality $\mathrm{HE}$ in this context is still very slow. ${ }^{4}$ Therefore, African/Cameroonian governments should be encouraged to freely provide $\mathrm{HE}$ based on their financial power; as well as decentralise the provision of HE by inviting eligible private partners to get involved. In this way, aid through conditionality provided to African/Cameroonian HE would

4 Despite multinational assistance allocated to $\mathrm{HE}$ around the 2000s, in Cameroon for instance, the development of quality $\mathrm{HE}$ is still very slow evident by the presence of just eight full fledge state-owned universities amidst many private institutions of higher learning. Many of these private HEIs do not have the full status of a 'university', cannot confer degrees and suffer from many crises which raise concerns about the quality of education they provide. It can be argued that if serious attention was paid to HE in the 80 s and 90s (just like basic education), there possibly would have been a smooth growth of quality $\mathrm{HE}$ in this context. 
have positive impacts on multinational finance of HEIs and educational policy borrowing.

In the quest of instituting professionalisation in universities as a good academic condition through the Structural Adjustment Programme (SAP), multinationals (e.g the World Bank) have indirectly encouraged youth unemployment crisis which is perceived as a negative academic condition. In line with this, an interviewee said:

The World Bank ... did not encourage selfemployment by giving youths alternative loans to start up their own self-employed businesses..... The World Bank ..... came up with a dead or mortuary-like Structural Adjustment Programme SAP, without any alternative follow-up to empower the youths. If the World Bank had followed up with a special Marshall Plan, for young people to borrow money which they could use to invest in self-employed projects, then SAP would have been more fruitful; and not just cutting off branches on which people, especially the youths were sitting on. (University officialG;BUST-2015).

In line with this quotation, data indicates that the introduction of SAP by The World Bank was aimed at controlling state employment as the state had too many people (for instance three people in one job position) while spending too much on workers. This implicitly did not provide equal employment opportunities for all youths coupled with huge government expenditure on those employed. In this regard, despite the introduction of strategies to solve youth unemployment like the institution of entrepreneurship and professionalisation, the lack of an ample Marshall-type Plan (an alternative source of income for young people to borrow money and invest in self-reliant economic projects) in order to reinforce the aforementioned strategies still pose problems for youth unemployment. Furthermore, according to some interviewees, though from an anthropological and sociological perspective, it is often said that the civil service does not produce income like the private sector, in Cameroon for instance, since the private sector which is supposed to be the main employer of youths is weak or does not really exist, it means this sector is out of question in terms of employment. According to an interviewee, this has been triggered by the Cameroonian 'omnipotent president' who has always encouraged public service jobs as the best way of maintaining power through paychecks because when people become very self-reliant, they also become very critical of the state which explains why the Cameroonian civil service has been and is still being described as '...the mortuary for young people, who have matricule numbers and just waiting to retire and die' (University official-G;BUST-2015) ${ }^{5}$. In this case, coupling Cameroon's 'mortuary-like' civil service and the World Bank's SAP have not been helpful in terms of youth empowerment, professionalisation and employment, hence a problem. To expand on this weakness, Matunhu (2011, p.67) argued that the imposition of IMF's Economic Structural Adjustment Programme - ESAP, aimed at alleviating poverty and underdevelopment in the 1980s has failed in Africa as a result of the lack of consideration of Africa's local, cultural and socio-political values. While SAP was created many years ago, according to some interviewees, this macro-economic policy still prevail and has been accelerated by the employability agenda of the Bologna Process reforms ${ }^{6}$. Therefore, to ameliorate concerns brought about by SAP relative to graduate unemployment as evident in the quotation above, there is need for the World Bank to establish a special Marshall Plan which is connected to the Structural Adjustment Plan (SAP) which would be an avenue for youths and university graduates to borrow money and invest in self-employed projects thus solving graduate unemployment, entrepreneurial and professionalisation concerns. This approach would likely bear implications for multinational finance of $\mathrm{HE}$ as well as educational policy borrowing.

While the use of foreign expertise has been considered a condition necessary to benefit from multinational and bilateral aids, the withdrawal of foreign expertise during foreign policy implementation is also considered a negative academic condition by participants. In line with this, an interviewee said:

...foreign NGOs help at least the country to be aware of things and also provide financial means....Five years and beyond these institutions are no more there to control the implementation of such policies and that is how these policies are just forgotten. (University official-B:2015).

It can be argued that the withdrawal of foreign expertise during policy, programme or reform implementation does not only pose concerns in terms of expertise needed for

\footnotetext{
${ }^{5} \mathrm{~A}$ matricule number is a unique number assigned to each civil servant in Cameroon as an indication of state employment.

6 The Bologna Process in Cameroonian HE is also called Licence-Master-Doctorat (LMD), Bachelor's-MastersDoctorate (BMD) or Bachelor's-Master's-PhD (BMP).
} 
implementation; but is one of the leading causes of lack of follow up or monitoring, systemic collapse or abandonment and overall lack of continuation of policies, programmes or reforms in this context. Therefore, to solve aid conditional problems related to the withdrawal of foreign expertise during foreign policy implementation within African/Cameroonian HE, multinationals need to constantly part-take in periodic monitoring and follow up of practices, programmes, policies and reforms to ensure continuity and sustainability. In this way, multinational finance of $\mathrm{HE}$ and educational policy borrowing would have more positive effects through aid conditionality.

It can be concluded that academic conditions are not always positive but negative too. However, negative academic conditions do not seem to advance the functioning of HEIs in Africa at large and Cameroon in particular as these have adverse economic repercussions on policies, practices and resources within HEIs in these contexts. While negative academic conditions might be intentional (for example restriction of access to $\mathrm{HE}$ ) and unintentional (for example youth employment crises), the bottom line is that these conditions do not seem to help HE systems grow but instead pose concerns. This means these sets of conditions need to be revised or discarded.

\section{Aid conditionality analogies: perceptions of aid conditionality as a problem}

'Analogies or metaphors of aid conditionality' is the use of analogies or metaphors to describe problems plaguing multinational finance of education and educational policy borrowing through the lens of aid conditionality in African/Cameroonian HEIs. . It has been argued that strings attached to conditions for debt cancellations by the IMF and World Bank for instance have led to other problems and this has been described by Jeffry Sachs as 'belt-tightening for people who cannot afford belts' (Mead, 2012). Apart from this existing metaphor, data also reveal three metaphors/analogies of aid conditionality including "he who pays the piper call the tune"; "there ain't no such thing as afree lunch"; and "aid to developing countries is colonialism in a new dress".

\section{"He who pays the piper call the tune"}

"He who pays the piper calls the tune" is a common adage and an idiomatic expression which according to this research denotes that, when someone is paying for the services of another, the former dictates exactly what he/she wants the latter to do as an eligibility condition to benefit from the deal. This provides not only a summary of conditionality from a metaphoric standpoint as seen above but provides detailed illustrations of other problems inherent to aid conditionality. In line with this, an interviewee said:

Foreign bodies dictate their policies. He who pays the piper, calls the tune! They said that if we do not use condoms as contraceptives, they will not sponsor us. They even had to come to our parliament and parliamentarians were forced to take condoms. But condoms is not the only way; ....which must be imposed. (University OfficialD;BUST-2015).

The quotation presents another category of academic conditionality known as non-academic conditionality with an example being the use of condoms as contraceptives to be eligible for foreign aids ${ }^{7}$. Some participants argued that the problem which further arises from non-academic conditions like use of condoms as contraceptives is that most Cameroonians who are not used to European or western lifestyles do not understand what this concept or condition mean. Therefore, it is unreasonable to bombard them with such foreign idiosyncrasies and cultures which are unknown to them. Some participants suggested that what westerners would have done is to teach Cameroonians and Africans such a concept and allow them to gradually accept and implement this at their own pace because when this is being passed as law, it becomes an injunction in getting aid which is wrong.

According to participants, "he who pays the piper call the tune" of the money is related to the relationship that exists between those who come up with policies (dominant class) and accompany these policies with money; and those who receive the money and implement the policies (aid recipients or beneficiaries). However, this relationship makes it easier for imposed policies (through aid conditions) to be easily accepted and adopted in Africa/Cameroon at large and their respective HE systems in particular without taking into consideration needs analysis and contextual realities hence posing problems for educational policy borrowing. Participants admit that "he who pays the piper call the tune" arises from conflict theory and unequal power relations because as the dominant class (multinationals and developed countries) have more power

\footnotetext{
7 The use of condoms as contraceptives is a non-academic condition originating from the health sector that has had potentials of affecting HE systems from political, health and economic standpoints.
} 
than Africa/Cameroon and their HE systems, such unequal power has become the gateway for Cameroonian $\mathrm{HE}$ to dance to their tune thus facilitating educational policy borrowing. Participants also claim that there are relatively very few African foundations (relative to the number of foreign foundations) that provide financial grants for research in universities either in the social or hard sciences as most of them are western grants, hence increasing the chances of dancing to the tune of foreign aid. An interviewee said:

Not just loans! Even what they call donations and assistance have strings attached to them. If I say I'm going to give you foreign aid of 500 million for the next five years, you start dancing to my tune, right! When you don't dance the way I want you to dance after five years, I will pull back my money, right? And because we have been used to that money, it will be difficult not to dance to their tune. (University Official-A;UB:2015).

I think in many ways, many policies emanating from the West are hurting because they are often strongly adopted rather than adapted. They have the money to encourage us to shape policies in certain ways using Bretton Wood institutions, the World Bank, the IMF, the UN and all its institutions including UNESCO. They make policies and send them to us as our objectives in whatever policy recommendations they are making. (University Official-A;UB:2015).

While the first quotation illustrate the analogy of aid conditionality with respect to "he who pays the piper call the tune", the second quotation reinforces the first quotation by stressing how hurtful or problematic this can be for educational policy borrowing in terms of policy adoption and implementation.

This indicates that policy borrowing from a metaphorical perception of "he who pays the piper calls the tune" or aid/donation/loan conditionality stipulated by wealthy bodies are not often favourable to African/Cameroonian governments and their universities. This confirms the argument that aid conditionality thus serve as problem for multinational finance of education and educational policy borrowing in Africa at large and Cameroon in particular within the framework of $\mathrm{HE}$.

\section{"There ain't no such thing as a free lunch"}

"There aint' no such thing as a free lunch" is a common adage which means it is impossible to get anything for free.
Within Africa's/Cameroon's HE in the domain of policy borrowing and particularly the aspect of support provided by multinationals and bilateral ties relative to donations/aids/loans/expertise, this adage implies that, African/Cameroonian HE do not get these support for free but pay back dearly. One of such academic conditionality with heavy setbacks is that of "expertise". To illustrate this, an interviewee said:

Well, the first one is technical assistance. If I'm going to give you money, I'm going to give you persons to train you [laughs sarcastically]. Most of that aid goes back to "technical assistance" that is paid back to the donor in many ways. Yes! There ain't no such thing as a free lunch! Again, the aid is not even as much as what they get from us in terms of raw materials. If you want to go the business way, I'd say we get very very little return for what we give in terms of raw materials. (University Official-C;SMU:2015).

Participants reiterated that when the Bachelor's-MastersDoctorate (BMD) reform was introduced in Cameroon, seminars conducted to train individuals on what the new system entailed were run by people coming particularly from France, The World Bank and the European Union who were for a mission lasting within a month. During that period, all lectures were halted in order to commercialise the BMD system. The problem did not only lie on students missing lectures, the heavy cost of hosting these foreign experts, but the whole idea of it being a condition in the sense that if Cameroonian HE did not accept these foreign experts and their mission, they would have nothing to write in their country report when demanding for foreign finance. It can be argued that this situation triggers superiority of foreign expertise over national or local indigenous expertise which have negative impacts on staff professional esteem; indigenous knowledge production; and indigenous human capital formation within the local African/Cameroonian context. Furthermore, it can be argued that giving financial aid on one hand in 'hiring' foreign experts to facilitate policy/programme implementation, while taking the financial aid back with another hand in the name of 'paying' these foreign experts ends up leaving African/Cameroonian $\mathrm{HE}$ with no financial aid hence a problem. Therefore, the evidence provided on "there ain't no such thing as afree lunch" which metaphorically depict problems plaguing multinational finance of education and educational policy borrowing through aid conditionality within African/Cameroonian HE systems is true. 
"Aid to developing countries is colonialism in a new dress"

The analogy "aid to developing countries is colonialism in a new dress" (Commonwealth Officia-C:2015); is an analogy which refers to problems associated to multinational finance of education and educational policy borrowing in African/Cameroonian HE resulting from aid conditionality rooted in colonialism, neocolonialism and/or postcolonialism. In contemporary society, Khelfaoui (2009) for instance noted that the adoption of the Bologna Process in Africa is perceived to be dis guised colonisation because the reform has been influenced by ex-colonial nations. According to some participants aid in Africa is a form of neocolonialism as Africa is considered a big market for westerners who need to sell their ideas through conditional aid transfer with only Africa that can consume them. An interviewee said:

....well, it is a form of neocolonialism in the sense that Africa is a big market for them and so, they need to sell these ideas and only Africa can consume them. (University OfficialA;UCAC:2015).

Another interviewee said 'Former colonial masters are still the ones that are doing the tune and the dancers are the people who were once colonised and are still being colonised.' (University Official-A;UB:2015). While this quotation provides evidence to the argument "aid to developing countries is colonialism in a new dress", it at the same time also provides evidence to the metaphor, "he who pays the piper call the tune". This means metaphors of aid conditionality depicting problems plaguing multinational finance of education and educational policy borrowing in African/Cameroonian HE systems are not mutually exclusive but symbiotically convey same meanings regardless of whatsoever examples that are being used for illustration.

Some participants claimed that due to the fact that the west is better developed in terms of having spent more time in university education among other developmental aspects, they do not only come up with policies but with money aimed at forging policies in directions which they believe in and which they think are good for Africans. Nonetheless, this have had devastating consequences as some interviewees have pointed to examples of African leaders who plunder resources in Africa to satisfy eximperialists and show greater loyalty to ex-imperialists. Thus:

www.jiels.com
Thanks to the fact that the west are better developed in terms of having spent more time in university education, they do not only come up with policies, they ....come up with money aimed at forging policy directions that they believe in, and think are good for us. They sponsor some African scholars to join the bandwagon. Where do they train these African scholars? In the World Bank, the IMF, the UN....They say when they come back they'll be presidents in their countries. They support them to be presidents in their countries, and what do they do? Help them to steal more and give them. Plunder!!! Who is the president of Ivory Coast today? Alassane Ouattara! The presidency of Ivory Coast is not in Ivory Coast. It is in France. The land on which the presidency of Ivory Coast is, is owned by French people. So, the Ivorians pay rents for their presidency. They should leave us alone. They should not tell us that they'll give money to us. (University Official-A;UB:2015).

To reinforce the above evidence, Haughton (2004) noted that from a postcolonial perspective, ex-imperialists (mothers) have kept their ex-colonies (babies) continuously poor and needy using a strategy which is to drop a penny and reap a pound and under such pressurized situations, the babies (ex-colonies) would continuously succumb to their mothers (ex-imperialists). However, it should be noted that this metaphor ties more with bilateral aid schemes (between ex-imperialists and ex-colonies) than multinational aid schemes. It can be argued that these western foreigners also cease the opportunity of re-colonising Africans/Cameroonians (regardless of the latter gaining independence some decades back) through the spread of western ideas during seminar presentations and other means. I call this situation the 'shadow of colonialism' or simply 'colonial shadowing' because colonial masters are not physically present but their ideas still rule and as similate ex-colonies; with other powerful countries and multinationals playing same rule to an extent.

Implications of aid conditionality for multinational finance of HEIs and educational policy borrowing in Africa/Cameroon: Learning from existing literature

Multinational finance of education and educational policy borrowing have been perceived to have strings attached to them harnessed through what is known as aid conditionality (Vuban, 2018). This section presents some implications of aid conditionality which have potentials of impacting on 
multinational finance of HEIs and educational policy borrowing. Based on findings, it can be argued that conditional aid pose disrespect for territorial sovereignty and national/institutional autonomy in Africa/Cameroon despite any impactful developmental motives which such aids may represent. Furthermore, by showing gratitude to foreign donors with regards to respecting the terms or conditions of aids/donations/loans, African/Cameroonian governments and their $\mathrm{HE}$ systems run the risk of continuously being indebted and dependent on foreign policies, aids/donations in a continuous manner which never seem to end. Borrowed from the ideas of Kanbur (2000, p.10), to resolve concerns associated to aid conditionality affecting aid reforms (e.g those associated to $\mathrm{HE}$ reform processes in Africa), multinational finance of HEIs and educational policy borrowing, the following suggestions are worthy to consider:

(1) There is need for more arms length relationships among recipients (Africa at large and Cameroon in particular) and aid donors to combat the dysfunctionality of (HE) systems in these contexts brought about by excessive intrusiveness of donors under the banner of aid effectiveness.

(2) There is need for both donors and recipients to establish a strict and firm modality for conditionality by modifying the incentive systems in both recipient nations (Africa/Cameroon) and their HE systems; and multinational donor agencies.

(3) An important step worth considering towards achieving a stricter arms length relationship on aid flows should be that of deep debt relief across Africa as a continent and Cameroon as a nation (which have potentials of affecting HE systems across these contexts).

(4) There is need for less obsession regarding the amount of aid with more attention focused on the consequences of aid dependence by both recipients (Africa/Cameroon and their $\mathrm{HE}$ systems); and multinational aid donors to ensure aid effectiveness.

(5) There is need to direct aid to good policy environments (for instance more attention need to be paid to positive academic conditionality than any other type of conditionality) and to motivate the emergence of these policy environments (Kanbur, 2000, p.3).

Oxfam (1995) postulated that for conditionality to work, it should be grounded on the right kinds of conditions. To
Spevacek (2010, p.2), implications for "new conditionality" (should) center around more flexibility, which entail: granting civil societies and recipient (African/Cameroonian) governments control of reform processes (both aid reforms and $\mathrm{HE}$ reforms) and periodic monitoring of implementations. There is also need to consider that successful and sustainable development (of HE systems in Africa at large and Cameroon in particular) must be grounded on symbiotic accountability, transparency, dialogue, commitment and partnership (p.3). Furthermore, analytical frameworks which have been developed to operationalise conditionality (Spevacek, 2010, p.3) need to be used. These include the need to:

- reinforce ownership of host (African/Cameroonian) governments;

- adapt conditionality to realities of the host nation (and HE contexts);

- emphasise on (HE) outcomes in Africa/Cameroon;

- improve (HE) harmonisation and coordination;

- enhance resource flow predictions (within African/Cameroonian HE);

- foster not only transparency but accountability within coordinated schemes (in African/Cameroonian $\mathrm{HE}$ );

- establish adequate responses to performances (in African/Cameroonian $\mathrm{HE}$ ) that are inadequate.

Riddell and Niño-Zarazúa (2016, p.30-31) also suggested that there are four vital aspects that could work better when dealing with foreign aid to education (which can also be applied within African/Cameroonian HE). These include the need to (1) reinforce capacity development, knowledge transfer and technical cooperation; (2) keep abreast with knowledge concerning the 'transferability' of aid-supported educational programmes; (3) enhance more South-South co-operation (related to African/Cameroonian HE); (4) reinforce knowledge regarding the scalability of aidsupported educational programmes (for African/Cameroonian HE).

\section{CONCLUSION}

This article sought to examine academic conditionality perceived as negative; metaphors of aid conditionality depicting problems; and some implications of aid conditionality for multinational finance of HEIs and educational policy borrowing in Africa/Cameroon by learning from existing literature. Examples of academic conditionality perceived as negative included restriction of access to HE, youth unemployment crisis, poor working conditions for university lecturers and withdrawal of 
foreign expertise during foreign policy implementation. To address aid conditionality problems associated to restriction of access to $\mathrm{HE}$ for instance, governments of African nations should be encouraged to decentralise the provision of HE by calling on private partners to be part of it thereby increasing equal access to $\mathrm{HE}$ for all. Furthermore, aid conditionality concerns related to youth unemployment crisis, can be solved by calling on The World Bank to establish a special Marshall Plan alongside the Structural Adjustment Plan (SAP) to provide an avenue for university graduates to borrow money and invest in self-employment thereby solving unemployment, as well as entrepreneurial and professionalization concerns. To address aid conditionality concerns related to poor working conditions for university lecturers, multinationals should encourage universities to be engaged in alternative sources of income generating activities which can be used to boost staff salaries - hence enabling good working conditions for staff which have potentials for positively impacting on the provision of quality education. Concerns related to the withdrawal of foreign expertise during foreign policy implementation, can be solved by calling on multinationals to be part of not only the adoption stage of HE reforms in Africa (Cameroon) or the initial phases of implementation, but should continuously partake in periodic monitoring and follow up to ensure continuity or sustainability of $\mathrm{HE}$ reforms, policies, programmes, and practices. Findings also presented three metaphors/analogies of aid conditionality which depict problems including "he who pays the piper call the tune"; "there ain't no such thing as a free lunch"; and "aid to developing countries is colonialism in a new dress".

Aid conditionality perceived as negative has stimulated the drive to examine the implications of aid conditionality for multinational finance of $\mathrm{HEI}$ and educational policy borrowing in Africa/Cameroon by learning from existing literature. Kanbur (2000) for instance suggested that there is need for more arms length relationships among aid recipients and aid donors to combat the dysfunctionality of (HE) systems within Africa/Cameroon brought about by excessive intrusiveness of donors under the banner of aid effectiveness. Furthermore, the article implies that whether for good or for bad, conditionality meted out by multinational/bilateral donors as a requirement to benefit from multinational/bilateral finance of $\mathrm{HE}$ systems in Africa/Cameroon apparently impedes absolute national sovereignty and national/institutional autonomy thus serving as a disincentive or problem for educational policy borrowing. Efforts need to be made by multinational/bilateral donors to encourage and reinforce academic conditionality perceived as positive in order to obtain a win-win relationship. To this effect, it is important to further research into academic conditionality perceived as positive as well as non-academic conditionality within African/Cameroonian HE systems in order to obtain a holistic picture of discourses on aid conditionality in these contexts to better inform decisions on what external sources of finance are needed and most beneficial in these contexts.

\section{ACKNOWLEDGEMENT}

I wish to thank Professor Paul Wakeling for reading and providing feedback to the first draft of the findings.

\section{DECLARATION OF INTEREST STATEMENT}

Not applicable!

\section{REFERENCES}

[1] African Development Bank. (2015). Poverty has declined in Africa but remains high. Chapter Two. p.28-54.

https://www.afdb.org/fileadmin/uploads/afdb/Docume nts/Publications/ADR15 chapter 2.pdf

[2] Ajayi, J., Lameck, K., Goma, G., \& Johnson, A. (1996). The African experience with higher education, Accra: The Association of African Universities. Athens: Ohio University Press.

[3] Altbach, P.G., Reisberg, L., \& Rumbley, L.E. (2009, July). Trends in global higher education: Tracking an academic revolution. UNESCO 2009 World Conference on Higher Education, Paris.

[4] Ashford, R., \& Biswas, S. (2010). Aid effectiveness, transaction costs and conditionality in the education sector. International Journal of Educational Development, 30(5),481-487.

[5] Barro, R J. (1991). Economic growth in a cross section of countries. The Quarterly Journal of Economics, 106(2), 407-443.

[6] Barro, R., \& Sala-i-Martin, X. (1998). Economic growth. Cambridge, MA: MIT Press.

[7] Benhabib, J., \& Spiegel, M. M. (1994). The role of human capital in economic development: Evidence from aggregate cross-country data. Journal of Monetary Economics, 34, 143-173.

[8] Birchler, K., \& Michaelowa, K. (2016). Making aid work for education in developing countries: An analysis of aid effectiveness for primary education coverage and quality. International Journal of Educational Development, 48, 37-52. 
[9] Bloom, N., Floetotto, M., Jaimovich, N., SaportaEksten, I. \& Terry. S. J. (2014). Really uncertain business cycles. Stanford University, mimeo.

[10] Bologna Declaration. (1999). Joint declaration of the European Ministers of Education. Bologna.

[11] Brinkmann, S. \& Kvale, S. (2015). Interviews: Learning the crafts of qualitative interviewing $\left(3^{\text {rd }}\right.$ ed.). London: Sage.

[12] Bryman, A. (2016). Social research methods (5 ${ }^{\text {th }}$ ed.). Oxford: Oxford University Press.

[13] Carr-Hill, R. A. \& King, K. (1992). International aid to basic education: flows, policies, modalities. Edinburgh: Centre of African Studies, Edinburgh University.

[14] d'Aiglepierrea, R. \& Wagner, L. (2013). Aid and universal primary education. Economics of Education Review, 37, 95-112.

[15] Doh, P. S. (2007). Harmonisation challenges in higher education: Case of the French and British bicultural system in Cameroon (Unpublished Master's thesis). Institute for Educational Research, University of Oslo, Norway.

[16] Doh, P. S. (2008). Global integration policies versus institutional dynamics of higher education. European Education, 40(1), 78-96.

[17] Ebongue, A. E. (2017). Cameroon's official bilingualism: Challenges and prospects. In I. PiotLepetit. (Ed.). Cameroon in the 21 st century challenges and prospects - environment and people: African Political, Economic and Security Issues (vol. 2, pp.315-331). Nova Science Publishers, Inc, New York.

[18] Eta, E. A. (2015). Policy borrowing and transfer, and policy convergence: justifications for the adoption of the Bologna Process in the CEMAC region and the Cameroonian higher education system through the LMD reform. Comparative Education, 51(2), 161-178.

[19] Eta, E.A. \& Vuban, J.A. (2018). Educational policy borrowing in the Cameroonian higher education system: A debatable paradigm from stakeholder perspectives. Forum for International Research in Education, 4(3), 77-94.

[20] Fonkeng, G. E. (2007). The history of education in Cameroon: 1884-2004. Queenstown Lampester, New York: The Edwin Mellen Press.

[21] Freeman, K. (2003). Higher Education and Multinational Corporations Linkages: establishing a mutual bond. Lessons for China from Redemocratized Hungary. Policy Futures in Education, 1, (2): 321331.

www.ijels.com https://journals.sagepub.com/doi/pdf/10.2304/pfie.200

3.1.2.8.

[22] IMF (WEO October 2018 Edition) GDP nominal and PPP data - international dollar. Retrieved from https://www.imf.org/external/datamapper/datasets/WE $\underline{\mathrm{O} / 1}$

[23] International Evaluation Group (IEG)-World Bank Group. (2017). Higher education for development: An evaluation of the World Bank Group's support. Washington: The International Bank for Reconstruction and Development/The World Bank.

[24] Jacob, W. J. \& Gokbel, V. (2018). Global higher education learning outcomes and financial trends: Comparative and innovative approaches. International Journal of Educational Development, 58, 5-17.

[25] Jacob, W. J., Neubauer, D. \& Ye, H. (2018). Financing trends in Southeast Asia and Oceania: Meeting the demands of regional higher education growth. The United Kingdom. International Journal of Educational Development, 58, 47-53.

[26] Kanbur, R. (2000). Aid, conditionality and debt in Africa. In F. Tarp. (Ed). Foreign aid and development: lessons learnt and directions for the future. Cornell University: Routledge.

[27] Kim, B. \& Park, N. (2018). Lessons learned from financing universal higher education in Korea. International Journal of Educational Development, 58, 116-127.

[28] Klemenčič, M. (2009). The Bologna Process and students' expectations. Understanding Bologna in context: Perspectives on the Bologna process - past and present; creating a European Higher Education Area. http://scholar.harvard.edu/files/manja klemencic/files/ mklemencic bologna handbook.pdf

[29] Laura, Z. (2010). Cacophonies of aid, failed state building and NGOs in Haiti: Setting the stage for disaster, envisioning the future. Third World Quarterly, 31(5), 755-771.

[30] MacOjong, T. T. (2008). Philosophical foundations of education in Cameroon, 1884-1960. Limbe: Design House.

[31] Marginson, S. (2018). Global trends in higher education financing: The United Kingdom. International Journal of Educational Development, $58,26-36$.

[32] Matunhu, J. (2011). A critique of modernization and dependency theories in Africa: Critical assessment. African Journal of History and Culture, 3(5), 65-72.

[33] Mbua, F. N. (2002). Educational planning: Issues and perspectives. Limbe: Presprint. 
[34] Ngoh, V. J. (2011). The untold story of Cameroon reunification: 1995-1961. Limbe: Pressprint PLC.

[35] Niño-Zarazúa, M. (2016). Aid, education policy, and development. International Journal of Educational Development, 48, 1-8.

[36] Novelli, M. (2010). The new geopolitics of educational aid: From Cold Wars to Holy Wars? International Journal of Educational Development, 30(5), 453-459.

[37] Oxfam. (1995). The Oxfam poverty report. Oxfam Publications.

[38] Patton, M. Q. (1990). Qualitative evaluation and research methods. (2nd ed.). Thousand Oaks, CA: Sage.

[39] Phillips, D. \& Ochs, K. (2004). Researching policy borrowing: Some methodological challenges in comparative education. British Educational Research Association, 30(6), 773-784.

[40] Poovey, M. (1995). Making a social body: British cultural formation 1830-1864. Chicago: University of Chicago Press.

[41] Radelet, S. (2010). Emerging Africa: How 17 countries are leading the way. (CDG Brief). Centre for Global Development.

[42] Rebelo, S. (1991). Long-run policy analysis and longrun growth. Journal of Political Economy, 99(3), 500521.

[43] Riddell, A. \& Niño-Zarazúa, M. (2016). The effectiveness of foreign aid to education: What can be learned? International Journal of Educational Development, 48, 23-36.

[44] Sayre, A. P. (1999). Africa. Twenty-First Century Books. ISBN 0-7613-1367-2.

[45] Spevacek, A. M. (2010). Aid and the "new" conditionality. USAID KNOWLEDGE SERVICES CENTER (KSC).

https://pdf.usaid.gov/pdf docs/pnadm068.pdf

[46] Steer, L. \& Wathne, C. (2010). Donor financing of basic education: Opportunities and constraints. International Journal of Educational Development, 30(5), 472-480.

[47] Steiner-Khamsi, G. (2006). The economics of policy borrowing and lending: A study of late adopters. Oxford Review of Education, 37(20), 151-171.

[48] Tambo, L. I. (2003). Principles and methods of teaching: an application in Cameroon schools. University of Buea. ANUCAM.

[49] Teichler, U. (2018). Recent changes of financing higher education in Germany and their intended and unintended consequences. International Journal of Educational Development, 58, 37-46.
[50] Temple, J. R. W. (2010). Aid and Conditionality. Handbook of Development Economics, 5, 4415-4523.

[51] Tilak, J. B. G. (1988). Foreign aid for education. International Review of Education, 3(3), 313-335.

[52] UNESCO Institute for Statistics. (2011). Financing education in Sub-Saharan Africa. Meeting the challenges of expansion, equity and quality. UNESCO Institute for Statistics, Montreal, Quebec, Canada.

[53] UNESCO. (2000). The Dakar framework for action. Education for All: Meeting our collective commitments. World Education Forum, Dakar, Senegal.

[54] United Nations. (2017). World population Prospects The 2017 revision. Key findings and advance tables. New York: United Nations. United Nations Department of Economic and Social Affairs Population Division. ESA/P/WP/248.

[55] Verger, A., Novelli, M., \& Altinyelken, H. K. (Ed.). (2012). Global education policy and international development: New agendas, issues and policies. London: Bloomsbury.

[56] Vuban, J. A. (2018). The influence of the Bologna Process on the harmonization of Cameroonian higher education. (Unpublished PhD thesis). Department of Education: University of York, United Kingdom.

[57] World Bank. (1999). The World Bank annual report 1999. Washington DC; World Bank.

[58] World Bank. (2000). Higher education in developing countries: peril \& promise. The Task Force on Higher Education \& Society.

[59] World Bank. (2002). Constructing knowledge societies. New challenges for tertiary education. Washington: World Bank.

[60] World Bank. (2010). Financing Higher Education in Africa. Washington DC: The International Bank for Reconstruction and Development / The World Bank. pp. $1-170$. https://www.kiva.org/cms/financing higher edu afric a.pdf

[61] World Bank. (2011). Learning for all. Investing in people's knowledge and skills to promote development. World Bank Group Education Strategy 2020. Executive Summary. Washington, DC: The World Bank.

[62] World Bank. (2014). PovcalNet 2014. World Bank: Washington DC. 